\title{
ARL Libraries and Staff Development: A Suggested Model for Success
}

\section{Pat Weaver-Meyers}

An education model of staff development, the Readiness, Planning, Training, Implementation, and Maintenance Model (RPTIM) is described. Concepts in the model are related to a broad overview of current staff development and continuing education efforts in academic libraries. Results of a survey of staff developers in ARL libraries suggest that 80 percent of the model describes practices appropriate to the academic/research library setting. In addition, respondents indicated that existing staff development programs generally did not meet the criteria staff developers agreed should be part of their libraries' program.

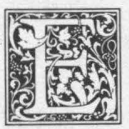

ffective continuing education and staff development programs in libraries are becoming more pressing needs as fastpaced change remains with us. Sheila Creth identifies continuing education as a priority and exhorts academic librarians to assess critically the degree of support continuing education receives from library administrators. ${ }^{1}$ This study examines RPTIM, the Readiness, Planning, Training, Implementation and Maintenance model. ${ }^{2}$ Devised for use with staff development programs for education professionals, RPTIM is a potentially valuable tool for improving staff development efforts in the field of academic librarianship as well. This study, which surveyed Association of Research Libraries (ARL) staff development and personnel officers, is offered in support of the RPTIM model's applicability to the academic library environment. The survey assesses the status of current ARL staff development library programs in relation to the ideal practices embedded in the model. The following review of library staff development and continuing education programs is provided as background to the survey results.

\section{CURRENT EFFORTS IN CONTINUING EDUCATION}

Continuing education (CE) and staff development (SD) are important components of librarianship in these days of rapid technological change and intensified career concerns. Elizabeth Stone, in her thorough analysis of continued learning in our profession, draws a distinction between $C E$ and SD programs. Specifically, she defines staff development as continued learning that fulfills the needs or goals of the institution and continuing education as any kind of learning experience that will introduce new skills or concepts, fulfilling the needs of the individual for career advancement and improved personal competency. ${ }^{3}$ Although such

Pat Weaver-Meyers is Access Services Department Head at the University of Oklahoma Libraries, Norman, Oklahoma 73019-0528. Much of the interpretation of the RPTIM model is taken primarily from a series of lectures presented by Fred $\mathrm{H}$. Wood. Assistance with the statistical analysis was provided by Robert Shull, University of Oklahoma Statistical Computing Laboratory. 
distinctions are important, particularly to this study, staff development and continuing education remain closely intertwined. In this paper, the focus will be on staff development as Stone defines it, but $\mathrm{CE}$ efforts will be reviewed due to their close relationship to staff development.

Several organizations provide CE opportunities to librarians. According to Brooke Sheldon, continuing education programs are being provided by numerous associations: American Society of Information Science, Special Library Association, the Continuing Library Education Network and Exchange of the American Library Association, International Federation of Library Associations, and others. ${ }^{4}$ However, extensive efforts by such organizations to provide "quantity and accessibility" have not been particularly successful. For example, Marion Paris and Herbert White indicate that continuing education in the area of special librarianship lacks a unified core of coursework related to special library issues. ${ }^{5}$ Brooke Sheldon points out that only a small percent of librarians participate regularly in CE offerings. ${ }^{6}$

A discussion of the quality assurance concerns of the associations and some analysis of their offerings are provided by Peggy O'Donnell, who concludes that association offerings are especially important since they represent "the concerns and voluntary professional involvement of the individual librarian." ${ }^{\prime 7}$ Sheldon's summary analyses of $\mathrm{CE}$ and $\mathrm{SD}$ in the most recent volumes of the ALA Yearbook demonstrate a high level of activity on the part of associations in developing programs and in analyzing the most effective organizational stance towards these efforts. ${ }^{8}$ Recently, a study sponsored by the Ontario Library Association analyzed various existing CE models with the intent of proposing an organizational coordinating body and defining its responsibilities.' This is one example of how library organizations are reassessing their commitment to $\mathrm{CE}$.

Regional and state library agencies are alternative providers of CE. William Asp and Suzanne Mahmoodi describe existing programs nationwide. ${ }^{10}$ Learning in Prog- ress by Joan Wright and Douglas Zweizig focuses on existing state programs and the coordination of all types of providers including library schools and associations. ${ }^{11}$ James Nelson points to coordinating, planning, financing, linking (to national and regional programs), licensing, providing, consuming and advocating as the major roles in $\mathrm{CE}$ and $\mathrm{SD}$ that should be assumed by stage agencies. ${ }^{12}$ In many cases public, although not necessarily academic, libraries benefit from the efforts of state agencies. Further, state agencies do much toward providing more staff development-type programming for nonprofessionals, rather than just CE for professionals.

Another logical provider of continuing education and staff development opportunities is the library school. Marilyn Miller provides a comprehensive analysis of the state of library schools in the continuing education effort. ${ }^{13}$ She cites certificates of advanced study and sixth-year programs as examples of CE programming. In addition, she analyzes the number of $\mathrm{CE}$ courses provided by schools. From this analysis, Miller concludes that library schools have lost the initiative and failed to seize the opportunity to assume a dynamic leadership role in this arena. However, she maintains that they continue to have a place in the continuing education system. One example of a healthy library school CE program is offered at the University of Wisconsin-Extension. ${ }^{14}$ This program involves teleconferencing of $\mathrm{CE}$ units in such subjects as management and automation. In brief, library schools, like associations and state agencies, appear to play one part in the overall continuing education effort. The other players in this effort are the individual and the employer.

\section{CURRENT EFFORTS IN STAFF DEVELOPMENT IN ACADEMIC LIBRARIES}

The preceding review has concentrated on continuing education, because it seems that CE offerings in the form of workshops, CEU training programs, and preconferences often constitute all the staff development some librarians encounter. This lack of in-house staff development is 
disturbing, since personal experience suggests that these $\mathrm{CE}$ programs, attended with enthusiasm and interest, can be quickly forgotten. What is taught is not always implemented in the workplace. This may be because it is not seen as relevant to the attendee's current duties, because of lack of interest, or because of lack of follow-up by the supervisor. This does not mean that such coursework for the expansion of an individual's skills is a waste. It is a necessary part of career development. The problem lies in the assumption by the institution that such programming represents an adequate staff development program.

Although staff development in some libraries may be limited to CE coursework, some academic institutions are recognizing that staff development requires a more complex response. In a recent article describing a residency training program at the University of Michigan Library, Richard Dougherty convincingly states that "the intellectual demands are too diverse, and time too short for library schools to assume the entire responsibility for training practicing librarians." 15 Although training new library graduates in practical applications is not new to library managers, Dougherty is emphasizing the responsibility of the library administrator to formalize strategies for such efforts. Ronald Powell's recent study suggests that ARL librarians would prefer to acquire more of their professional knowledge through continuing education and staff development activities. ${ }^{16}$ What is the current trend in academic libraries? The following section examines current staff development and training programs in academic libraries with the intention of laying a framework for the use of the RPTIM model in a systematic staff development effort.

On-the-job training has been employed by libraries. The Office of Management Services/Association of Research Libraries has recognized the need to improve training and has developed a new course that focuses on the learning process. It is directed toward personnel officers and staff involved in coordinating training activities. This is one of many institutes and programs offered by OMS. According to their 1987 annual report, OMS has trained over 7,000 librarians since $1973 .{ }^{17}$ The emphasis of OMS has been on self-study programs and the use of institute and retreat formats in training programs is consistent with current research in the most effective adult training techniques.

The Association of College and Research Libraries (ACRL) is another provider of $\mathrm{CE}$ opportunities for academic librarians. Through local state chapters, their coursework is accessible to many unable to participate in national preconferences. Although these organizations, particularly OMS with its onsite applied approach toward training, provide important development opportunities, the consistent application of this training within the library remains a responsibility of the individual and the institution.

In addition to institutes, OMS has a spec kit program that pulls together in-house documents from different libraries. These kits serve as resources for self-training in academic libraries and provide a simple yet effective form of peer exchange. Several other recent publications provide a compendium of effective training techniques in all types of libraries. ${ }^{18}$ Although their coverage is not limited to paraprofessionals, most of these works emphasize practical training approaches to clerical tasks. The British seem to excel in developing such programming, but paraprofessional training is also present in American academic libraries. Jacquelyn Gavryck describes a program developed at the SUNY Albany Libraries. ${ }^{19}$ What is particularly noteworthy about this program to train clerical staff is that an existing cadre of trainers was used to provide training within the organization rather than bringing trainers in from the outside. The assignment of personnel charged with the coordination of staff training efforts has occurred in larger academic libraries and a movement in this direction is gaining momentum in smaller academic libraries as well.

Evidence of an increased emphasis on in-house training is demonstrated in the Resource Notebook on Staff Development by Jane Rosenberg and Maureen Sullivan. ${ }^{20}$ 
This volume contains examples of current efforts in staff development at various academic libraries. The inclusion of program statements used at various institutions is also useful. These authors stress that changes in library organization increase the need for a dynamic process of staff development. Defining career ladders and job exchange are two ideas suggested. The concept of diversifying staff and promoting flexibility fits with a new emphasis in the quality of work life, cited by Rosenberg and Sullivan as an important trend forwarded by Charles Martell. ${ }^{21}$ Importantly, these authors conclude that the formal acknowledgement of staff development programming is a necessary prerequisite to formal budgetary commitment.

Jana Varlejs addresses budgetary commitment on the part of library administrators through modeling of costs. In one example, she compares in-service training to off-site training. ${ }^{22}$ Varlejs further raises the question of how much should be spent for adequate staff development and suggests that modeling may be used to arrive at a possible recommendation. Once a budgetary commitment is made, a closer examination of effective programs is necessary to insure value for each dollar spent. Examination of proven models of staff development is one method of arriving at a successful strategy.

\section{"Research by Jana Varlejs suggests that learning styles should be taken into consideration in the formulation of continuing education and staff de- velopment work."}

Such an examination of models in continuing education has been done in the formulation of much of our present-day library continuing education. ${ }^{23}$ Model comparison and formulation in staff development practice are now being done. Margaret Trask describes several presuppositions in Australian libraries' staff development, which can serve as a base model and Christian Vink suggests some practical guidelines as well. ${ }^{.4}$ Malcolm Knowles has put forth a model based on adult learning theory, which in may ways parallels the RPTIM model this paper will examine. ${ }^{25}$ Furthermore, research by Jana Varlejs suggests that learning styles should be taken into consideration in the formulation of continuing education and staff development work. ${ }^{26}$ The RPTIM model does this. Finally, the RPTIM model has been applied to higher education personnel, not the group for which it was originally formulated, and found to be an appropriate guide for staff development. $^{27}$

\section{THE RPTIM MODEL}

The RPTIM model has five major subdivisions from which the acronym is formed: readiness, planning, training, implementation, and maintenance. Within these broad categories are thirty-eight specific practices that are stressed as important ingredients in an effective staff development program. In their original presentation of the model, Fred Wood, Steven Thompson, and Sister Francis Russell forward these categories as essential to a "coherent paradigm for constructing (staff development) programs. ${ }^{\prime 28}$ In addition to the 38 practices, the authors based their model on a series of assumptions or beliefs. The model was supported by practitioners in teacher/staff development. ${ }^{29}$ The following is a brief description of these categories as they relate to the academic library environment.

Readiness, the first step in the model, refers to the establishment of a positive work climate for staff development. This climate is characterized by the development of trust among colleagues, support, and open communication between administrators and staff. A clear vision of the organization's goals are put forth by the library director, and the administration and staff work together to formulate goals that will achieve the vision.

Why is readiness a necessary component of the staff development process? One reason is that change is a high-risk venture for an individual and activities such as team-building exercises foster a sense of support and gain the trust of 
those involved. In addition, readiness is a time when loyalty for the chosen goals is established and participation gives everyone the sense of ownership necessary for successful change. Also, readiness activities refocus the attention of the group away from present concerns toward a new agenda. The Management Review and Analysis Program used by the Office of Management Studies, Association of Research Libraries and other OMS self-study programs include some of these concepts. ${ }^{30}$ Readiness is not then a totally new concept in library management, but seems to be infrequently applied in any systematic manner in staff development programming.

Some of the existing programs in academic libraries detailed in Resource Notebook on Staff Development indicate a climate that provides opportunities for staff development, but little mention is made of team building or actual staff input into defining beneficial staff development opportunities. ${ }^{31}$ The Texas A\&M staff exchange/sharing program is a positive exception. This program allows departments to plan, outline and train participants in an employee exchange program. ${ }^{32}$ However, in goal formulation and analysis of options, the participation of staff in libraries still seems limited. Systematic connection between organization goals and staff development is also rare.

Planning, the second component of the RPTIM model, generally occurs in most organizations, and academic libraries are no exception. Most academic libraries can produce a plan or policy for staff development when asked. However, how was that plan devised? Was information on weaknesses and strengths in work practices gathered from the staff? Did the plan include assessment of participants learning styles or was it based on research findings about adult learners? Did the planners determine how the program related to a long-term plan for improvement and did they include a list of in-service resources such as videotapes, university personnel staff development offerings, money for trainers, release time available, or in-house experts? Who did the planning-personnel officers, directors, or everyone? These questions exemplify the focus of this stage in the model.

Needs assessment, a part of planning, is being done in academic libraries. Rosenberg and Sullivan include some good examples of survey forms designed to ascertain staff needs. ${ }^{33}$ In addition, their suggestions for information gathering include many of the steps in this model.

Training steps in the RPTIM model might best be understood by asking the following questions. Did the training program divide the group into teams to discuss and share experiences? Were the training program objectives chosen by group consensus? Who selected the program and was attendance required? Did the training program include practice sessions in which all the participants could try out the new behaviors presented during training? Was the training program presented by colleagues? Did the library director or a supervisor attend the session? Were group leaders experts in the subject presented, or were they department heads or divisional leaders? As the training session progressed, did the trainer expect the participants to rely more on themselves to generate activities? Did the participants emerge from the training session more confident?

Sue Courson's and Kenna Forsyth's public library program, in which librarians were given training in adult learning theory, learning objectives, needs assessment, training styles, transfer of learning and evaluation, and the new OMS course on training trainers, is evidence of increased awareness of these questions in library staff development. ${ }^{34}$ Stone also discusses quality control issues that relate to the concerns in this step of the model. ${ }^{35}$

The implementation criteria in the RPTIM model seem to be ignored most when libraries rely on continuing education opportunities to fulfill staff development needs. Most continuing education programs stop at an evaluation survey passed out during the last fifteen minutes of the session. Libraries could maximize CE offerings by sending more than one participant. When they returned to the workplace, they could observe one another using the new work practices, thereby en- 
hancing implementation. Following up with resource support would also assist. Such follow-up activities are not common in CE coursework, but are sometimes emphasized in on-the-job training. On-site institutes such as those provided by OMS improve the chances of implementation through the use of applied techniques.

Maintenance is a method of assuring that the new work practices are stabilized and continued. The level of success with maintenance is usually reflected in performance evaluations. Some self-evaluation techniques are also used to maintain new work behaviors. However, self-evaluation is underutilized. Most maintenance is closely tied to personnel office procedures that address performance evaluation. There is no problem with this approach, as long as it does not lead to a consistently negative view, lack of positive feedback, and an inadequate period of time to implement the change before evaluation takes place. What seems to be missing is the use of measures that reflect improvement in overall quality with regard to the change in work practice.

Measuring increased efficiency in cataloging is merely one use of quantitative techniques for determining the effects of change in work procedure. They are quite rightly used. Qualitative changes are harder to measure, and perhaps for that reason seem to remain unrelated to staff development efforts. The debate about effective performance measures will continue for many years to come. ${ }^{36}$ Once these measures become more refined, they should be included in the evaluation of staff development programs. It should be emphasized that staff development ultimately rests on the assumption that improvement and change in job practice benefits the organization and the individual. Furthermore, organizational improvement should be measurable in terms of the patron's rate of success in filling information needs.

\section{METHOD}

In April of 1988, a questionnaire surveying RPTIM model practices was mailed to the staff development and personnel librarians in all ARL member libraries. Ap- pendix A reproduces the survey form. The form is adapted from the survey form originated by Steven Thompson and used by Ana Albino to assess perceptions of faculty development practices in higher education personnel. ${ }^{35}$ Wording was altered as little as possible and most changes related to position titles e.g., librarian = teacher or director $=$ principal. One additional question was added, belief ten. The first section of the survey lists ten beliefs or assumptions that underlie the model and asks respondents to rate whether they agree or disagree with the statements.

The second section of the survey lists the thirty-eight practices that comprise the model. In this section, respondents are asked to rate the degree to which they think these practices should be part of library staff development efforts and the degree to which they think the practices now exist in staff development efforts in their library. The survey closed with a query about who is responsible for staff development and the number of staff in the library. The question of size was used later as a control, because earlier research shows that size is highly correlated with change and the adoption of new technology, the end result of many staff development programs. ${ }^{38}$ One hundred and sixteen surveys were mailed with a response rate of 47 percent.

The objective of the survey was twofold. First, a confirmation of the model as appropriate to the academic and research library setting was sought. Second, a measurement of the current state of staff development in these libraries in comparison to the model's criteria was reviewed to determine how current staff development efforts might be improved.

\section{FINDINGS}

General descriptive analysis of respondents shows that 26 libraries qualified as small with fewer than 200 staff members. Large libraries, with staff greater than 200 , accounted for 24 respondents. One respondent failed to complete the question. Fourteen libraries indicted they had staff development offices. When asked who was responsible for staff development programming, the responses varied con- 
siderably. Two libraries indicated no one had that responsibility while one library indicated that university personnel training services performed this role. Several libraries indicated individual supervisors and administrative officers were responsible. Most frequently, personnel managers, staff development officers, or personnel managers in conjunction with professional development committees were responsible.

\section{"Staff should be closely involved in the planning and selection of a pro- gram."'}

The use of a committee made up of paraprofessionals and professionals charged with establishing training priorities closely follows the planning techniques stressed in the RPTIM model. The model suggests that staff should be closely involved in the planning and selection of a program. A professional development committee was listed by seventeen of the responding libraries as the party responsible for staff development. One library indicated it had such a committee, but it was a committee for paraprofessional training. Professionals were held responsible for their own continuing education.

Although the questionnaire was mailed to the "personnel/staff development librarian" the title of the respondents confirmed that not all libraries have such a person. Directors, personnel librarians, assistant directors, and chairs of profes- sional development committees completed the forms. General commentary indicated that several libraries were newly involved in staff development programs and had hopes of increasing their commitment. One library emphasized the importance of shared responsibility between the organization and the individual. Another indicated that evaluation was important but was underemphasized in the RPTIM model. Three respondents mentioned that they were unclear about the difference between continuing education, inservice, on-the-job training and staff development and therefore had trouble answering some parts of the survey.

Quantitative analysis of the data focused on the two objectives of the study. The mean of each question was examined to determine if respondents agreed with the beliefs and practices the model listed. If the mean response was less than 3.0, the questions were considered unimportant by respondents and excluded from analysis. The remaining responses were deemed important to the survey group. Beliefs 6,8 and practices $16,21-25$, and 32 were excluded. This left a total of eight beliefs and thirty-one practices that were supported by respondents. Table 1 is a list of the means for the eight questions concerning beliefs.

Table 2 is a list of all the practices with a mean greater than 3.0 in the "should" categories. In addition, the table lists the F and $p$ values for the repeated measures MANOVA (multivariate analysis of variance) compiled for the difference between "should" and "exists" (statistics compiled by the SAS General Linear Models Procedure). The table shows significant values for all the questions.

TABLE 1

MEAN OF RESPONSES TO MODEL BELIEFS $>3.00$

\begin{tabular}{lccc}
\hline \hline Questions & $\mathrm{n}$ & $\bar{x}$ & STD \\
\hline 1. Library personnel need inservice & 54 & 3.53 & .63 \\
2. Significant improvement takes time & 54 & 3.01 & .71 \\
3. Inservice education focus on improving & 54 & 3.12 & .58 \\
4. Staff motivated to learn new things & 53 & 3.35 & .48 \\
5. Staff varies in competencies and readiness & 54 & 3.37 & .55 \\
7. The working climate influences success & 53 & 3.52 & .54 \\
9. The library has responsibility for providing resources & 52 & 3.05 & .60 \\
10. The library should provide inservice activities & 52 & 3.11 & .58 \\
\hline
\end{tabular}


TABLE 2

DIFFERENCE BETWEEN SHOULD AND EXISTS

FOR THOSE QUESTIONS WITH A MEAN $>3.00$

\begin{tabular}{|c|c|c|c|c|c|}
\hline Questionst & $\mathrm{n}$ & $\begin{array}{c}\text { should } \\
\bar{x}_{1}\end{array}$ & $\begin{array}{l}\text { exists } \\
\bar{x}_{2}\end{array}$ & $\begin{array}{l}\text { difference } \\
\bar{x}_{1}-\bar{x}_{2}\end{array}$ & $\mathrm{~F}^{*}$ \\
\hline 1. A positive work climate is developed & 52 & 3.34 & 2.59 & .75 & 44.165 \\
\hline 2. Library goals written collaboratively & 52 & 3.41 & 2.56 & .85 & 43.764 \\
\hline 3. Improvement goals for three to five years & 53 & 3.60 & 2.73 & .87 & 33.284 \\
\hline 4. The library staff adopts goals & 52 & 3.51 & 2.66 & .85 & 41.974 \\
\hline 5. Current library practices are examined & 48 & 3.39 & 2.50 & .89 & 47.305 \\
\hline 6. Current work practices are examined & 51 & 3.09 & 2.25 & .84 & 57.614 \\
\hline 7. Staff identifies plans to achieve goals & 53 & 3.24 & 2.56 & .68 & 41.057 \\
\hline $\begin{array}{l}\text { 8. Leadership responsibility of library } \\
\text { (a) director/dean }\end{array}$ & 52 & 3.51 & 2.96 & .55 & 25.591 \\
\hline (b) associate directors/deans & 52 & 3.51 & 3.08 & .43 & 30.966 \\
\hline (c) staff development officer & 49 & 3.77 & 3.32 & .45 & 10.348 \\
\hline 9. Differences of desired and actual practices & & & & & \\
\hline $\begin{array}{l}\text { are examined } \\
\text { 10. Planning of staff activities relies on }\end{array}$ & 54 & 3.33 & 2.44 & .89 & 67.392 \\
\hline information & 54 & 3.42 & 2.94 & .48 & 23.597 \\
\hline 11. Inservice planners use information & 54 & 3.14 & 2.03 & .84 & 82.886 \\
\hline $\begin{array}{l}\text { 12. Staff development include inservice } \\
\text { activities }\end{array}$ & 54 & 3.00 & 1.71 & 129 & 97.137 \\
\hline 13. Resources are identified prior to planning & & & & & \\
\hline 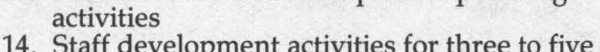 & 53 & 3.50 & 2.98 & .52 & 22.563 \\
\hline years & 53 & 3.09 & 1.73 & 1.36 & 132.242 \\
\hline 15. Specific objectives are written & 53 & 3.45 & 2.36 & 1.09 & 54.807 \\
\hline $\begin{array}{l}\text { 17. Staff development objectives include } \\
\text { knowledge }\end{array}$ & 53 & 3.45 & 2.96 & 85 & 25.432 \\
\hline $\begin{array}{l}\text { 18. Staff development objectives include skill } \\
\text { development }\end{array}$ & & & & & \\
\hline $\begin{array}{l}\text { development } \\
\text { 19. Leadership is shared amo }\end{array}$ & 53 & 3.37 & 2.86 & .51 & 23.479 \\
\hline $\begin{array}{l}\text { 19. Leadership is shared among librarians } \\
\text { 26. Leaders selected according to expertise }\end{array}$ & $\begin{array}{l}53 \\
53\end{array}$ & $\begin{array}{l}3.28 \\
3.45\end{array}$ & 3.55 & $\begin{array}{l}.73 \\
.34\end{array}$ & $\begin{array}{l}45.767 \\
12.718\end{array}$ \\
\hline 27. Leadership behavior becomes less directive & 48 & 3.04 & 2.61 & .43 & 24.805 \\
\hline 28. Leader transfers responsibility & 49 & 3.32 & 2.54 & .78 & 65.145 \\
\hline 29. Participants have access to support services & 50 & 3.38 & 2.12 & 1.26 & 101.069 \\
\hline 30. Library staff members are recognized & 52 & 3.46 & 2.35 & 1.11 & 82.096 \\
\hline $\begin{array}{l}\text { 33. Resources are allocated to support new } \\
\text { practices }\end{array}$ & 51 & 3.25 & 2.1 & 1.13 & 77.939 \\
\hline 34. The library director support changes & 51 & 3.62 & 3.02 & .60 & 24.955 \\
\hline 35. Systematic program is used & 53 & 3.09 & 2.07 & 1.02 & 60.536 \\
\hline 36. Library staff use systematic techniques & 52 & 3.07 & 1.84 & 1.23 & 127.887 \\
\hline 37. Performance used to monitor new practices & 52 & 3.01 & 1.98 & 1.03 & 75.675 \\
\hline 38. Responsibility for maintenance is shared & 52 & 3.42 & 2.39 & 1.03 & 62.308 \\
\hline
\end{tabular}

*Wilks Lambda values

$+\mathrm{p}<.05$ for all questions, $\mathrm{df}_{\mathrm{btw}}=1$

This suggests that the staff development programs in ARL libraries fall short of what experts in the field agree should exist. As shown in table 2, all but four of the practices that should be part of staff development according to respondents fell below the 3.0 level when respondents rated the programs in their libraries.

As mentioned earlier, libraries were grouped in small and large categories to determine if size had any significant effect on responses. No significant difference was found in a repeated measures MANOVA (multivariate analysis of variance) of the two-by-two interaction between should-exists and small-large. In addition, ANOVA (analysis of variance) results of tests between small and large libraries show no significant difference with the exception of readiness one, a question concerning the importance of positive work climate. This question had an $F$ value of 4.48 with $p=.0394$. The mean values were greater for small libraries indi- 
cating the smaller library respondents supported the importance of positive work climate and felt it existed to a greater degree in their libraries.

\section{DISCUSSION}

The survey results suggest that academic and research library staff developers feel that 80 percent of the RPTIM model practices should be part of staff development efforts in their libraries. In addition, there is a significant difference between existing conditions and what these same developers feel should be part of their library's programs. Although the RPTIM model is not comprehensive, it may be an appropriate beginning checklist for academic and research libraries interested in improving their staff development programming.

Most of the practices in the RPTIM model that were not confirmed by the survey fall in the training category. Further research is needed to discover why experiential activities, peer teaching, selfdetermination and participation by administrators are not important concepts to library staff developers. Perhaps few librarians have personal experience with staff development that includes these practices. Also learning theory-based techniques may be more familiar to educators, the groups surveyed in earlier studies.

An important trend can be seen in the difference column in table 2 . Those questions with the greatest difference between what should be and what exists in staff development programs occurred in planning, implementation, and maintenance.
This suggests that academic libraries interested in improving their programs might concentrate limited resources in these areas. In addition, those organizations involved with continuing education programming that is fulfilling staff development needs should place some emphasis on the use of training after participants return to their offices.

There are some important limitations to this study. As mentioned earlier, a few respondents were confused about the general definitions of in-service, staff development, continuing education, and on-the-job training. No effort was made to define the concepts in a survey introduction, so it must be presumed that respondents answered based on their own interpretation of staff development. Four respondents expressed difficulty in interpreting questions or felt some of the wording was ambiguous. Also, comments suggested that evaluation of the quality of staff development programs should be a part of the model. One respondent questioned the need to formalize staff development to such a degree.

Further research using parallel models should be done to confirm these findings. Additional refinement of the RPTIM model by including a section on evaluation and by revising the section on training should be part of any further testing. This study serves as an initial focus in the review of appropriate practice in academic and research library staff development and can be used by personnel officers and administrators as a guide in planning the most effective programs possible.

\section{REFERENCES AND NOTES}

1. Sheila Creth, "National Adult and Continuing Education Week," College and Research Libraries News 47:657-58 (Nov. 1986).

2. Fred H. Wood, Steven R. Thompson, and Sister Frances Russell, "Designing Effective Staff Development Programs," in Staff Development/Organization Development, ed. by Betty DillionPeterson (Alexandria, Va.: Association for Supervision and Curriculum Development, 1981) p.59-91.

3. Elizabeth Stone, "Toward a Learning Community," in Continuing Education for the Library Information Professions ed. by William G. Asp (Hamden, Conn.: Shoe String Press, Inc., 1985) p.61-64.

4. Brooke Sheldon, "Personnel and Employment: Continuing Education and Staff Development," ALA Yearbook of Library and Information Services: A Review of Library Events 12:233-35 (1986). 
5. Marion Paris and Herbert S. White, "Mixed Signals and Painful Choices: The Education of Special Librarians," Special Libraries 77:207-11 (Fall 1986).

6. Brooke Sheldon, "Personnel and Employment: Continuing Education and Staff Development."

7. Peggy O'Donnell, "Continuing Education and Library Associations," in Continuing Education for the Library Information Professions, p.119-47.

8. The ALA Yearbook of Library and Information Services: A Review of Library Events contain summaries of current offerings and trends in CE and staff development annually.

9. Ethel Auster and Laurent-G. Denis, "Striving Toward Excellence: Continuing Education for Library Personnel," Canadian Library Journal 43:81-89 (April1986).

10. William G. Asp and Suzanne H. Mahmoodi, "Continuing Education and the State Library Agency," in Continuing Education for the Library Information Professions p.151-68.

11. Joan Wright and Douglas Zweizig, Learning in Progress: A Study of Continuing Library Education in North Carolina, (Raleigh, N.C.: North Carolina State University, 1982).

12. James A. Nelson, "State Agencies and Continuing Education Opportunities," in Continuing Education: Issues and Challenges: Papers From the Conference Held at Moraine Valley Community College, Palos Hills, Illinois, USA, August 13-16, 1985 ed. by Esther E. Horne (New York, N.Y.: Saur, 1985) p.157-63.

13. Marilyn L. Miller, "Library Schools and Continuing Education," in Continuing Education for the Library Information Professions p.213-75.

14. Darlene E. Weingand, "Continuing Education: The Wisconsin Experience," in Continuing Education for the Library Information Professions p.414.

15. Richard M. Dougherty, "A Nexus of Education and Practice: The Residency Program at the University of Michigan Library-The Underlying Rationale," Library Journal 111: 118-20 (Feb. 15, 1986).

16. Ronald R. Powell, "Sources of Professional Knowledge for Academic Librarians," College \& Research Libraries 49:332-40 (July 1988).

17. Office of Management Studies, Association of Research Libraries, 1987 OMS Annual Report (Washington: OMS, ARL, 1988).

18. Sheila D. Creth, Effective On-the-Job Training: Developing Library Human Resources (Chicago: American Library Assn., 1986); Ronald J. Edwards, In-Service Training in British Libraries: Its Development and Present Practice (London: The Library Association, 1977); Ray Prytherch, Handbook of Library Training Practice (Brookfield, Vt.: Gower, 1986); Ray Prytherch, Staff Training in Libraries: The British Experience (Brookfield, Vt.: Gower, 1986); Michael John Wells, Staff Training in University Libraries: Final Report for the Period June 1982-February 1983 (Aberstwyth: College of Librarianship Wales, 1983).

19. Jacquelyn Gavryck, "Library Instruction for Clerical Staff: The Rest of the Iceberg" Journal of Academic Librarianship 11:343-45 (Jan. 1986).

20. Jane A. Rosenberg and Maureen Sullivan, Resource Notebook on Staff Development (Washington, D.C.: Office of Management Studies, ARL, 1983).

21. Charles R. Martell, Jr., The Client-Centered Academic Library: An Organizational Model (Westport, Conn.: Greenwood Press, 1983).

22. Jana Varlejs, "Cost Models for Staff Development in Academic Libraries," Journal of Academic Librarianship 12:359-64 (Jan. 1987).

23. Elizabeth W. Stone, Continuing Library Education as Viewed in Relation to Other Continuing Professional Education Movements (Washington, D.C.: American Society for Information Science, 1974); Elizabeth Stone, Eileen Sheahan and Katherine J. Harig, Model Continuing Education Recognition System in Library and Information Science (New York: K.G. Saur, 1979).

24. Margaret Trask, "Interconnections in the Library and Information Science Career Development Process," in Continuing Education: Issues and Challenges p.142-55; Christian M. Vink, "In-Service Training By the Employer As a Continuing Education System," in Continuing Education: Issues and Challenges p.189-97.

25. Malcolm S. Knowles, "Understanding the Adult Learner," in Continuing Education: Issues and Challenges p.13-20.

26. Jana Varlejs, "Learning Styles of Librarians and Satisfaction with Continuing Education Activities: Looking for a Match," in Continuing Education: Issues and Challenges p.131-39.

27. Ana M. Delgado Albino, A Survey and Analysis of Puerto Rico Accredited Institutions of Higher Education Personnel Perceptions of Faculty Development Practices and Beliefs with a View to Identifying Some Critical Needs (Ph.D. diss., Pennsylvania State University, 1983).

28. Fred H. Wood, Steven R. Thompson, and Sister Frances Russell, "Designing Effective Staff Development Programs," p.59.

29. Ibid., p.61-63. 
30. Duane Webster, Library Management Review and Analysis Program: A Handbook for Guiding Change and Improvement in Research Library Management Volume II: Manual. (Washington, D.C.: Office of University Library Management Studies, Association of Research Libraries, 1973).

31. Jane A. Rosenberg and Maureen Sullivan, Resource Notebook on Staff Development.

32. Ibid., p.182.

33. Ibid., p.9-50.

34. M. Sue Courson and Kenna Forsyth, "Maryland's Staff Development: Training of Trainers," in Continuing Education: Issues and Challenges p.407.

35. Elizabeth Stone, "Toward a Learning Community," p.89-106.

36. George D'Elia, "'Output Measurement-State of the Art: Materials Availability Fill Rates-Useful Measures of Library Performance?"' Public Libraries 24:106-10 (Fall 1985).

37. Steven R. Thompson, A Survey and Analysis of Pennsylvania Public School Personnel Perceptions of Staff Development Practices and Beliefs with a View to Identifying Some Critical Problems or Needs (D.ED. diss., Pennsylvania University, 1982); Ana M. Delgado Albino, A Survey and Analysis of Puerto Rico Accredited Institutions of Higher Education Personnel.

38. Fariborz Damanpour and Thomas Childers, "The Adoption of Innovations in Public Libraries," Library and Information Science Research 7:231-46 (1985).

\section{APPENDIX A. RPTIM QUESTIONNAIRE SURVEY FORM}

\section{STAFF DEVELOPMENT SURVEY}

Below you will find a list of beliefs that could shape practices for staff development. Next to each statement there is a column of numbers.

Please indicate the degree to which you agree with the statement by circling the number beneath the appropriate descriptor.

1. All library personnel need inservice throughout their careers.

2. Significant improvement in library programs and services takes considerable time and long-term inservice programs.

3. Inservice education should focus on improving the quality of library programs and services.

4. Library staff are motivated to learn new things when they have some control over their learning and are free from threat.

\section{Library staff vary widely in their competencies and} readiness to learn.

6. Professional growth requires commitment to new performance norms.

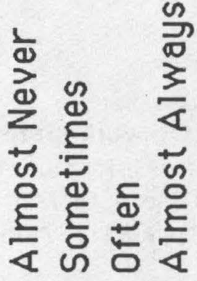

$123 \quad 4$

$\begin{array}{llll}1 & 2 & 3 & 4\end{array}$

$\begin{array}{llll}1 & 2 & 3 & 4\end{array}$

$\begin{array}{llll}1 & 2 & 3 & 4\end{array}$

$\begin{array}{llll}1 & 2 & 3 & 4\end{array}$

$1 \quad 2 \quad 3 \quad 4$


7. The working climate of the library, including such factors as social climate, trust, confidence, open communication, and support from colleagues for changes in practices, influences the success of professional development.

8. The library is the most appropriate target of change in work practice, not the university or the individual.

9. The library has the primary responsibility for providing the resources and training necessary for library staff to establish new programs and improve efficiency.

10. The library should provide inservice activities to insure the application of continuing education training.

$\begin{array}{llll}1 & 2 & 3 & 4\end{array}$

$\begin{array}{llll}1 & 2 & 3 & 4\end{array}$

$\begin{array}{llll}1 & 2 & 3 & 4\end{array}$

$\begin{array}{llll}1 & 2 & 3 & 4\end{array}$

Listed below you will find statements that could be used to describe several practices in library staff development programs. Next to each statement there are two columns.

In the first column, please indicate, placing a circle round the numberbeneath the appropriate descriptor, the degree to which you believe each practice describes what should be in your library to guide the design of staff development programs. In the second column, indicate the degree to which you believe the practice describes what exists in your library.

SHOULD BE EXISTS

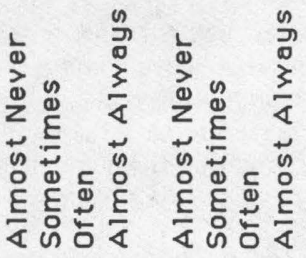

\section{READINESS}

1. A positive work climate in the library is developed before other staff development efforts are attempted (a positive climate is characterized by open communication, confidence, trust and supportive relationships).

$1234 \quad 1234$

2. Goals for library improvement are written collaboratively by staff, librarians, library administrators, and personnel office staff.

3. The library has a written list of goals for the improvement of library programs during the next three to five years.

4. The library staff adopts and supports goals for the improvement of library programs and services.

5. Current library practices are examined to determine which ones are congruent with the library's goals for improvement before staff development activities are planned.

6. Current work practices recommended in the literature and found in best practice are examined to determine which ones are congruent with the library's goals for improvement before staff development activities are planned. 
7. The library staff identifies specific plans to achieve the library's goals for improvement.

$1234 \quad 1234$

8. Leadership and support during the initial stage of staff development activity are the responsibility of the library

a) director/dean

$1234 \quad 1234$

b) associate directors/deans

c) staff development officer

$1234 \quad 1234$

$1234 \quad 1234$

\section{PLANNING}

9. Differences between desired and actual practices in the library are examined to identify the inservice needs of the staff.

10. Planning of staff development activities relies, in part, on information gathered directly from library staff members.

11. Inservice planners use information about the learning styles of participants when planning staff development activities.

12. Staff development programs include objectives for inservice activities covering three to five years.

13. The resources available for use in staff development are identified prior to planning inservice activities.

14. Staff development programs include plans for activities to be conducted during the following three to five years.

15. Specific objectives are written for staff development activities.

16. Staff development objectives include objectives for attitude development (new outlooks and feelings).

17. Staff development objectives include objectives for increased knowledge (new information and understanding).

18. Staff development objectives include objectives for skill development (new work behaviors).

19. Leadership during the planning of inservice programs is shared among librarians, staff and administrators.

TRAINING

20. Staff development activities include the use of learning teams in which two to seven participants share and discuss learning experiences.

21. Individual library staff members choose the staff development objectives for their own professional learning.

22. Individual library staff members choose the staff development activities in which they participate. 
23. Staff development activities include experiential activities in which participants try out new behaviors and techniques.

24. Peers help to teach one another by serving as inservice leaders.

$1234 \quad 1234$

$1234 \quad 1234$

staff development activities with their staffs.

26. Leaders of staff development activities are selected according to their expertise rather than their position.

$1234 \quad 1234$

27. As participants in staff development activities become increasingly competent, leadership behavior becomes less directive or task-oriented.

$1234 \quad 1234$

28. As participants in staff development activities become increasingly confident in their abilities, the leader transfers increasing responsibility to the participants.

$1234 \quad 1234$

IMPLEMENTATION

29. After participating in inservice activities, participants have access to support services to help implement new behaviors as part of their regular work.

$1234 \quad 1234$

30. Library staff members who attempt to implement new learning are recognized for their efforts.

$1234 \quad 1234$

31. The leaders of staff development activities visit the job setting, when needed, to help the inservice participants refine or review previous learning.

32. Library staff members use peer supervision to assist one another in implementing new work behaviors.

33. Resources are allocated to support the implementation of new practices following staff development activities (funds to purchase new materials or technologies, time for planning, and so forth).

$1234 \quad 1234$

34. The library director and associate directors actively support efforts to implement changes in professional behavior.

$1234 \quad 1234$

\section{MAINTENANCE}

35. A systematic program of supervision is used to monitor new work behavior.

$1234 \quad 1234$

36. Library staff members utilized systematic techniques of self-monitoring to maintain new work behaviors.

$1234 \quad 1234$

37. Library performance measures are used to monitor new practices.

$1234 \quad 1234$

38. Responsibility for the maintenance of new practices is shared by the librarians, staff, and administrators. 
Please state the position title of the person completing

this form

Is there an office of staff development in your library? -yes no.

If not, describe who is responsible for such efforts.

Approximately how large is your library system?

(please circle the correct answer)
a) 150-200 total staff
b) 200-250 total staff
c) 250-300 total staff
d) 300-350 total staff
e) 350-400 total staff
f) more than 400 total staff

Thank you for taking the time to complete this survey.

Any comments?

Form adapted from the original and used with the permission of Steven R. Thompson. 


\section{To Stay Ahead in Science and Technology...}

\section{You Need Bowker's A\& I Journals.}

\section{Comprehensive, World wide Coverage of Today's Crucial SciTech Issues!}

In today's world, up-to-date and accurate information on science and technology is vital. Each week, hundreds of science and technology periodicals publish thousands of important articles that can make a significant difference in your work.

Where can you turn for help in finding that information? Bowker's A\&I Journals! Offering easy access to current developments in robotics, artificial intelligence, and CAD/CAM, as well as coverage of a multitude of topics related to the environment, energy, and acid rain, Bowker's A\&I Journals provide incisive abstracts drawn from the scientific and technical literature published world-wide. These abstract journals will make research faster and easier and help you do your job better.

\section{Reference Resources for Everyone}

Whether your patrons are scientists engaged in research, business people who depend on closely monitored news, public officials involved in policy formulation, or members of the public looking for the hard facts, Bowker's A\&/ monthly* Journals provide information on everything from renewable resources to robotic locomotion to waste management, as well as thousands of other topics.

\section{Convenient and Easy-to-Use}

Compiled by specialists in their fields, each Journal's abstracts provide an accurate, comprehensive 100-word summary of each entry, plus all the bibliographic information needed for further research. With its vast array of current literature, the $A \& /$ Journals free you from time-consuming information searches by allowing patrons to work independently with research sources screened and compiled in one place.

\section{In-Depth Coverage}

Indexing over 1,800 scientific, technical, academic, and related journals published in over 50 countries, Bowker's A\&/ Journals also provide access to a wide range of conference proceedings, government studies, patent publications, and other significant, hard-to-find materials.

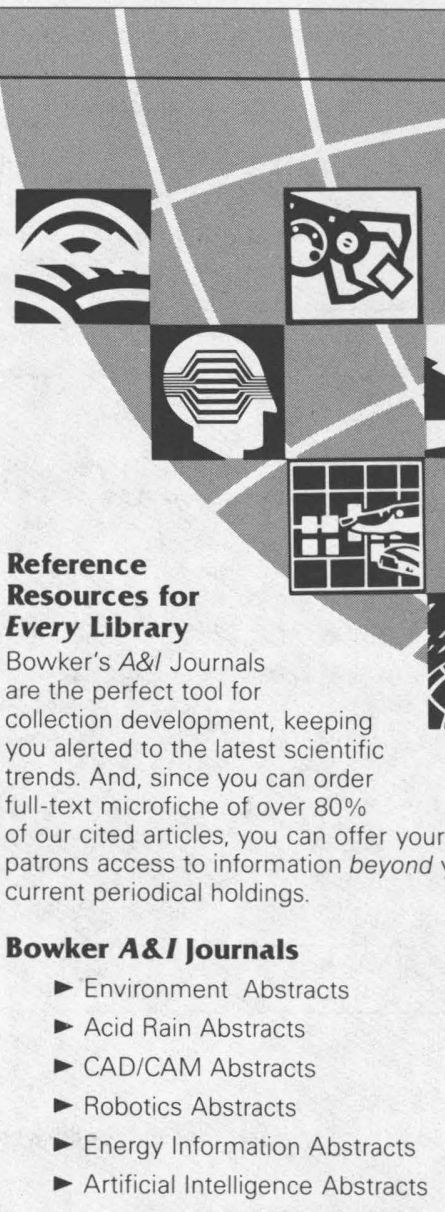

Bowker's A\&/ Journals are also available online or in annual cumulative volumes.

\section{Call Now For a Free Sample Journal!}

To order, or for more information about our integrated services of monthly journals, annual indexes, microfiche, and online databases,

\section{CALL TOLL-FREE 1-800-521-8110}

(In NY, AK, or HI call collect 1-212-463-6869).

*bi-monthly for Acid Rain.



245 West 17th Street, New York, NY 10011 